\title{
PENGARUH MADDEN-JULIAN OSCILLATION TERHADAP DISTRIBUSI TEMPORAL DAN PROPAGASI HUJAN BERDASARKAN PENGAMATAN RADAR CUACA \\ (Studi Kasus : Intensive Observation Period 2016 di Wilayah Jakarta dan Sekitarnya)
}

\author{
The Influence of Madden-Julian Oscillation on Temporal Distribution and \\ Rain Propagation Based on Weather Radar Observation \\ (Case Study : 2016 Intensive Observation Period \\ in the Jakarta Area and Its Surroundings)
}

\author{
Ardhi Adhary Arbain ${ }^{1{ }^{*}}$, Findy Renggono ${ }^{2)}$, Rino Bahtiar Yahya ${ }^{3)}$ \\ ${ }^{1,2,3)}$ Balai Besar Teknologi Modifikasi Cuaca - Badan Pengkajian dan Penerapan Teknologi, Gedung Ir. \\ Mohammad Soebagio, GEOSTECH (820), Kawasan PUSPIPTEK, Serpong, Tangerang Selatan \\ ${ }^{1)}$ Atmosphere and Ocean Research Institute (AORI), The University of Tokyo, Japan \\ *E-mail : ardhi.adhary@bppt.go.id
}

\begin{abstract}
Intisari
Distribusi temporal dan propagasi hujan selama Intensive Observation Period 2016 (IOP 2016, 18 Januari - 16 Februari 2016) di wilayah Jakarta dan sekitarnya dianalisis berdasarkan rataan longitudinal dan latitudinal data Constant Altitude Plan Position Indicator (CAPPI) radar cuaca, pada periode sebelum, saat dan sesudah fase aktif Madden-Julian Oscillation (MJO). Hasil analisis menunjukkan bahwa distribusi temporal hujan berkurang secara signifikan pada periode MJO aktif dan sesudah MJO, terutama pada dini hari. Di sisi lain, intensitas hujan semakin meningkat dengan nilai rata-rata di atas $30 \mathrm{~mm} / \mathrm{jam}$ pada periode setelah MJO. Pada komponen zonal, arah propagasi hujan umumnya dominan dari barat ke timur pada ketiga periode analisis, sedangkan untuk komponen meridional, terdapat variasi yang cukup signifikan pada periode saat dan setelah MJO aktif . Pergerakan hujan dari selatan ke utara pada kedua periode tersebut menunjukkan pengaruh siklus diurnal yang semakin kuat dibandingkan pengaruh monsun, setelah MJO melintasi wilayah barat Benua Maritim Indonesia.
\end{abstract}

Kata Kunci : MJO, Radar, CAPPI, Hujan.

\begin{abstract}
Temporal distribution and propagation of rainfall during Intensive Observation Period 2016 campaign (IOP 2016, January 18 - February 16, 2016) in Jakarta and surrounding area were investigated based on the longitudinal dan latitudinal averages of Constant Altitude Plan Position Indicator (CAPPI) dataset of weather radar, during the active Madden-Julian Oscillation (MJO) phase, as well as, pre-MJO and post-MJO periods. The results show a significant decrease of rainfall temporal distribution during the active MJO and post-MJO periods, particularly in the early morning, meanwhile, the rainfall intensity shows significant increase, with the averages of more than $30 \mathrm{~mm} / \mathrm{hr}$ during the post-MJO period. On the zonal component, the rainfall mostly has eastward propagation for all period while having more significant variations on the meridional component during the active and post-MJO periods. Northward rainfall propagation during the active and post-MJO periods indicates the strengthen effect of diurnal cycle over monsoon after the MJO passed by the western part of Indonesian Maritime Continent.
\end{abstract}

Keywords : MJO, Radar, CAPPI, Rainfall.

\section{PENDAHULUAN}

Madden-Julian Oscillation (MJO) (Madden \& Julian, 1994), atau disebut juga osilasi intraseasonal MJO, adalah elemen terbesar dari variabilitas intraseasonal dengan periode $30-90$ hari di atmosfer wilayah tropis, dengan karakteristik utama yakni adanya wilayah peningkatan dan penurunan curah hujan yang bergerak berpasangan mengelilingi bumi dari barat ke timur, dan umumnya terjadi di sepanjang Samudera Hindia hingga Samudera Pasifik. MJO mempengaruhi cuaca tropis secara signifikan, khususnya di Samudera Hindia, Benua Maritim 
Indonesia (BMI) dan Samudera Pasifik bagian barat.

Beberapa studi tentang MJO aktif dan pengaruhnya terhadap BMI telah dilakukan sebelumnya, misalnya oleh Chang et al. (2005), Hidayat \& Kizu (2010), Hattori et al. (2011), Kamimera et al (2012), Wu et al. (2007, 2013) dan Peatman et al. (2014). Secara umum, studistudi tersebut lebih menitikberatkan pada pengaruh MJO dalam skala regional, dengan memanfaatkan data spasial dari satelit maupun pengamatan dengan rawinsonde. Wu et al. (2013) mencoba menggunakan data radar cuaca dalam jangka pendek (3 hari) untuk menguji pengaruh MJO aktif terhadap variabilitas curah hujan dan banjir Jakarta pada bulan Januari 2013, namun efek MJO secara detil pada wilayah daratan (inland) Jakarta dan sekitarnya dalam skala lokal masih belum dapat dipahami dengan baik karena keterbatasan data beresolusi tinggi.

Balai Besar Teknologi Modifikasi Cuaca Badan Pengkajian dan Penerapan Teknologi (BBTMC-BPPT), bekerja sama dengan Badan Meteorologi Klimatologi dan Geofisika (BMKG) telah melakukan kegiatan Intensive Observation Period (IOP) selama periode puncak musim hujan tahun 2016 untuk mengetahui cuaca ekstrim penyebab banjir di wilayah Jakarta dan sekitarnya. Kegiatan ini berlangsung selama 30 hari, mulai tanggal 18 Januari hingga 16 Februari 2016. Beberapa instrumen pengamatan in-situ dan penginderaan jauh digunakan untuk mengamati karakteristik hujan di wilayah Jakarta dan sekitarnya, baik secara spasial maupun temporal, misalnya radar cuaca, micro rain radar, radiometer, radiosonde maupun stasiun cuaca otomatis (Automatic Weather Station).

Makalah ini mencoba mengkaji pengaruh MJO terhadap distribusi temporal dan pergerakan (propagasi) hujan di wilayah Jakarta dan sekitarnya, selama periode Intensive Observation Period 2016 (IOP2016) yang bertepatan dengan fase aktif MJO pada bulan Januari-Februari 2016, dengan menggunakan data radar cuaca $X$-band Doppler dualpolarimetric (DPR). Radar cuaca diperlukan untuk analisis spasial, dalam hal ini untuk mengetahui distribusi temporal dan propagasi hujan selama periode IOP, yang tidak dapat dilakukan dengan instrumen in-situ seperti penakar hujan. Informasi tentang distribusi temporal dan propagasi hujan dari data DPR nantinya akan digunakan untuk analisis interaksi antara MJO dengan variabilitas lokal seperti siklus diurnal, maupun monsun barat laut yang skalanya lebih besar, serta kontribusinya terhadap kejadian banjir Jakarta pada musim hujan.

\section{METODE}

Data utama yang digunakan pada penelitian ini adalah data Constant Altitude Plan
Position Indicator (CAPPI) dari radar cuaca $\mathrm{x}$ band dual-polarimetric Doppler WR-2100 yang dioperasikan di kantor BBTMC-BPPT, kawasan PUSPIPTEK Serpong, dengan spesifikasi seperti yang ditunjukkan pada Tabel 1.

Tabel 1. Spesifikasi Radar Cuaca BBTMC pada IOP 2016.

\begin{tabular}{|c|c|}
\hline Type & $\begin{array}{l}\text { WR-2100 Compact Dual } \\
\text { Polarimetric X-band Doppler } \\
\text { Weather Radar }\end{array}$ \\
\hline Manufacturer & Furuno Electric Co.Ltd. \\
\hline Location & $\begin{array}{l}\text { BBTMC, PUSPIPTEK Serpong } \\
\text { (106.68 BT, } 6.35 \text { LS) }\end{array}$ \\
\hline Observation & Horizontal sequence (HSQ) \\
\hline Frequency & $9470 \mathrm{MHz}$ \\
\hline Peak power & 100 watt \\
\hline Beamwidth & $2.7 \mathrm{deg}$ \\
\hline Range & $50 \mathrm{~km}(\max )$ \\
\hline $\begin{array}{l}\text { Sampling } \\
\text { space }\end{array}$ & $100 \mathrm{~m}$ \\
\hline $\begin{array}{l}\text { Elevation } \\
\text { Angles (deg) }\end{array}$ & $\begin{array}{l}0.5,1.5,2.4,3.4,4.3,5.3,6.2 \\
7.5,8.7,10,12,15\end{array}$ \\
\hline Time interval & 5 minutes \\
\hline
\end{tabular}

Data CAPPI diperoleh dari hasil pengolahan data pengamatan Horizontal Sequence Scan (HSQ) dengan 12 sudut elevasi dalam interval 5 menit, selama total 28 hari, mulai dari 20 Januari - 16 Februari 2016. Periode kalibrasi radar pada tanggal 18 dan 19 Januari 2016 tidak diikutsertakan dalam analisis.

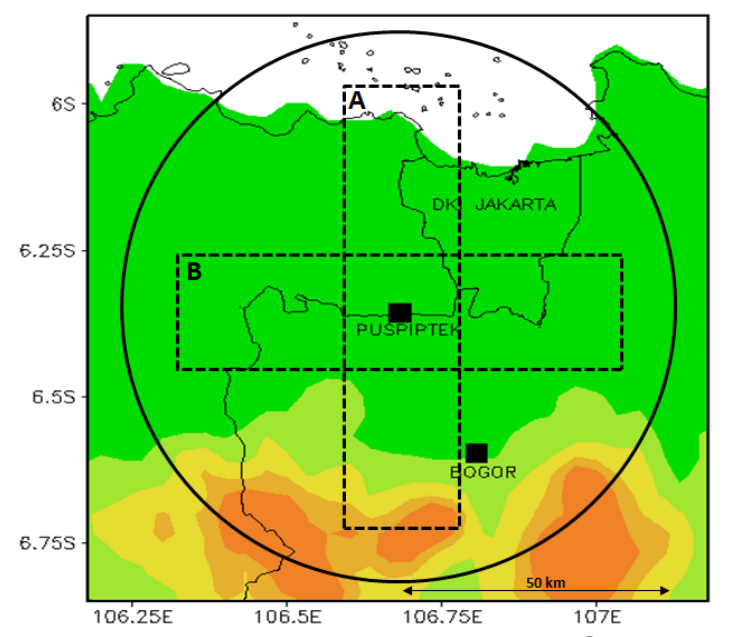

Gambar 1. Lokasi radar cuaca di PUSPIPTEK dan jangkauan maksimumnya (lingkaran hitam) selama periode IOP2016. (Kotak dengan garis putus-putus $A$ menunjukkan wilayah rataan untuk analisis intensitas hujan dalam arah meridional, sedangkan kotak B menunjukkan wilayah rataan untuk analisis intensitas hujan dalam arah zonal)

Data CAPPI yang diolah memiliki format binary dengan resolusi spasial 500 meter dan jangkauan maksimal 50 kilometer dalam arah horizontal (Gambar 1), serta 20 kilometer dalam arah vertikal. WR-2100 memiliki 8 jenis parameter pengamatan, yaitu; Reflectivity 
(dBuZ), Differential Reflectivity (ZDR), Differential Phase Shift (PhiDP), Specific Differential Phase Shift (KDP), Doppler Velocity (V), Correlation Coefficient (RhoHV), Spectral Width (W) dan Rainfall Intensity (Rain). Karena fokus penelitian ini adalah propagasi curah hujan, maka parameter yang digunakan untuk analisis hanyalah Rain.

Propagasi hujan dianalisis berdasarkan rataan intensitas hujan, baik secara longitudinal maupun latitudinal, pada daerah dalam kotak $A$ dan B yang ditunjukkan pada Gambar 1, yang masing-masing memiliki luasan $20 \mathrm{~km}$ x $80 \mathrm{~km}$.

Daerah dalam kotak A digunakan untuk analisis propagasi hujan dalam arah meridional (utara-selatan), sedangkan daerah dalam kotak B digunakan untuk analisis propagasi hujan dalam arah zonal (timur-barat). Ketinggian paras data CAPPI yang digunakan dalam analisis adalah 2 kilometer, untuk menjamin pergerakan hujan terbebas dari pengaruh gesekan permukaan bumi di bawah ketinggian boundary layer.

Keterbatasan radar yang digunakan ketika IOP adalah pada jangkauannya yang hanya maksimal $50 \mathrm{~km}$. Selain itu, akibat atenuasi atmosfer, kualitas data radar $X$-band makin buruk pada tepi daerah jangkauannya, sehingga untuk menjamin keseragaman kualitas data, maka analisis dalam studi ini dibatasi hanya sampai $10 \mathrm{~km}$ dari tepi jangkauan radar.

Intensitas hujan dapat diestimasi berdasarkan hubungan antara faktor reflectivity (Z) dan ukuran hydrometeor (R) dengan menggunakan rumus Malshall-Palmer (1948):

$$
Z=200 R^{1.6}
$$

Untuk mengetahui pengaruh MJO terhadap propagasi hujan selama periode IOP, hasil rataan intensitas hujan digambarkan dalam diagram Hovmoller pada beberapa periode, berdasarkan data indeks real-time multivariate MJO (RMM) (Wheeler \& Hendon, 2004) yang diperoleh dari Bureau of Meteorology, Australia (BOM) (Gambar 2). Berdasarkan indeks RMM, periode analisis dibagi ke dalam tiga kelompok, yaitu periode Sebelum, Saat dan Setelah MJO Aktif. Periode MJO Aktif untuk wilayah Jakarta dan sekitarnya didefinisikan sebagai periode ketika posisi indeks RMM telah memasuki fase 4 atau wilayah barat Indonesia (Maritime Continent).

Di sisi lain, periode Sebelum dan Setelah MJO Aktif masing-masing didefinisikan sebagai periode ketika MJO belum memasuki fase 4 (misalnya, fase 2 atau 3) dan periode ketika MJO telah melewati fase 4 (misalnya, fase 5 atau 6), seperti yang ditunjukkan pada Tabel 2. Indeks RMM juga menunjukkan amplitudo indeks >1 selama periode IOP 2016, yang mengindikasikan bahwa MJO aktif yang terjadi di wilayah Jakarta dan sekitarnya pada periode tersebut tergolong kuat.

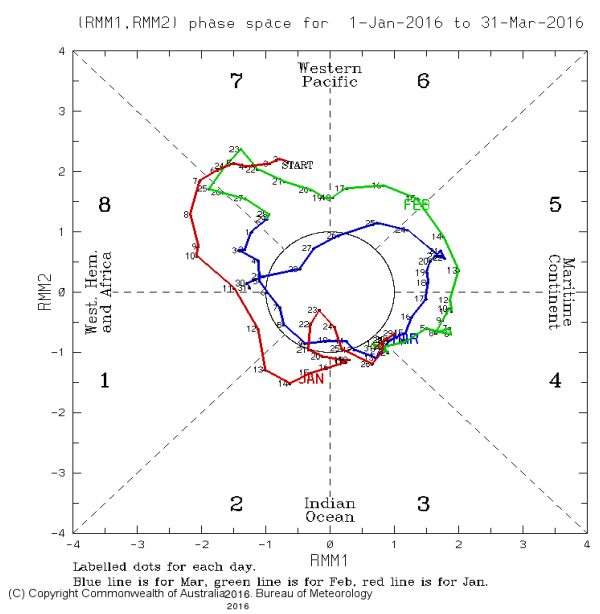

Gambar 2. Index RMM selama bulan JanuariMaret 2016. (Periode MJO aktif pada bulan Januari digambarkan dengan kurva merah, sedangkan periode Februari digambarkan dengan kurva hijau) (Sumber: BOM, Australia).

Tabel 2. Pengelompokkan Periode Analisis Intesitas Hujan Berdasarkan Fase Aktif MJO Selama IOP 2016.

\begin{tabular}{|c|c|l|}
\hline \multicolumn{1}{|c|}{ Periode } & $\begin{array}{c}\text { Fase } \\
\text { MJO } \\
\text { (RMM) }\end{array}$ & \multicolumn{1}{|c|}{ Kelompok } \\
\hline 20 - 23 Januari & 2 & Sebelum MJO Aktif \\
\hline 24 - 27 Januari & 3 & Sebelum MJO Aktif \\
\hline 28 - 30 Januari & 4 & MJO Aktif \\
\hline 31 - 3 Februari & 3 & Sebelum MJO Aktif \\
\hline 4 - 12 Februari & 4 & MJO Aktif \\
\hline 13 - 14 Februari & 5 & Setelah MJO Aktif \\
\hline 15 - 16 Februari & 6 & Setelah MJO Aktif \\
\hline
\end{tabular}

\section{HASIL DAN PEMBAHASAN}

Gambar 3 dan Gambar 4 menunjukkan diagram Hovmoller dari rata-rata intensitas hujan selama periode IOP 2016, masing-masing dalam arah zonal dan meridional. Bagian plot yang menyerupai garis atau persegi dengan intensitas $0 \mathrm{~mm} / \mathrm{jam}$ mengindikasikan data kosong (blank) yang kemungkinan diakibatkan oleh gangguan pada radar. Pola persegi lainnya dengan intensitas di bawah $3 \mathrm{~mm} / \mathrm{jam}$, yang terlihat dominan dalam radius $10 \mathrm{~km}$ (Gambar 3 ) dan pada bagian selatan dari lokasi radar (Gambar 4), diduga merupakan noise dan ground clutter dari daerah pegunungan di sebelah selatan lokasi radar. Pola diurnal hujan terlihat jelas dari Gambar 3 dan Gambar 4, dengan intensitas tertinggi (>30 mm/jam) umumnya terjadi pada sore hingga dini hari. Beberapa kejadian hujan juga terjadi hampir sepanjang hari, misalnya pada tanggal 24-25 Januari dan 1-2 Februari 2016. Hujan umumnya bergerak dari barat ke timur selama periode IOP 2016, terutama akibat pengaruh monsun barat laut dan MJO yang memiliki arah pergerakan yang relatif sama. Di sisi lain, propagasi hujan terlihat lebih bervariasi 


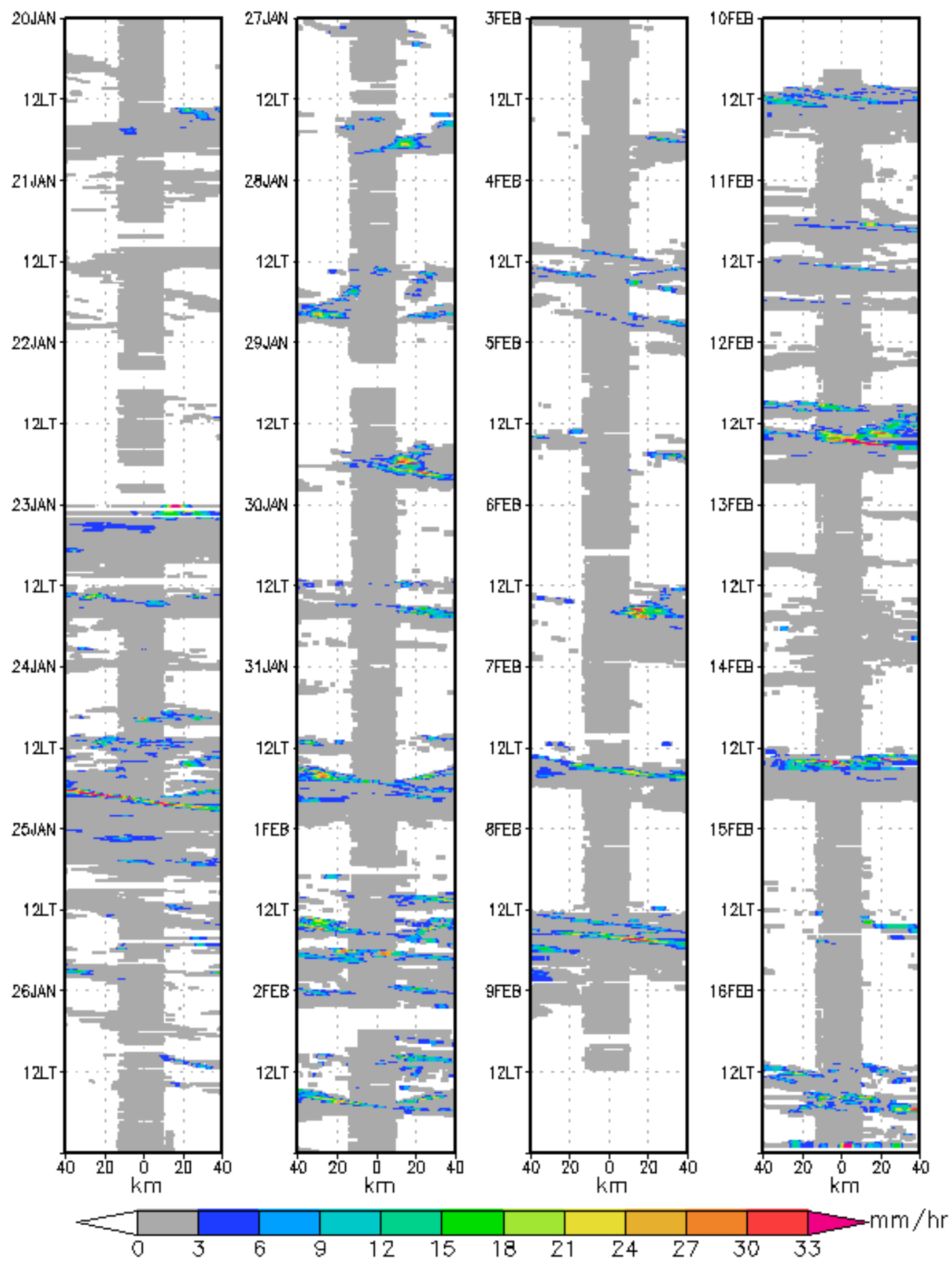

Gambar 3. Rataan dalam arah zonal (rataan latitudinal) intensitas hujan dari wilayah dalam kotak B pada gambar 1 selama periode IOP2016. Absis pada masing-masing plot menunjukkan jarak dari lokasi radar (misalnya, $40 \mathrm{~km}$ di sebelah kiri adalah $40 \mathrm{~km}$ di sisi barat lokasi radar).

secara meridional dan pada beberapa periode tertentu, tidak memiliki arah propagasi yang jelas.

Gambar 5 menunjukkan rataan 24 jam dari intensitas hujan selama 28 hari (20 Januari - 16 Februari 2016) dalam komponen zonal dan meridional, pada periode sebelum, saat dan sesudah MJO aktif. Pada periode sebelum MJO aktif, distribusi hujan umumnya lebih merata sepanjang hari, terutama pada sore, malam dan dini hari (12LT-03LT). Pada periode ini, hujan cenderung lebih banyak bergerak dari arah barat ke timur, walaupun terdapat variasi di sisi sebelah timur lokasi radar $(10-40 \mathrm{~km})$, di mana hujan bergerak dari arah timur ke barat pada pukul 13LT-18LT. Pada periode MJO aktif, hujan juga lebih dominan bergerak dari barat ke timur, namun distribusinya lebih rendah dibandingkan periode sebelum MJO aktif, terutama pada dini hari. Pada periode sesudah MJO aktif, hujan lebih banyak terjadi setelah pukul 11LT-18LT. 

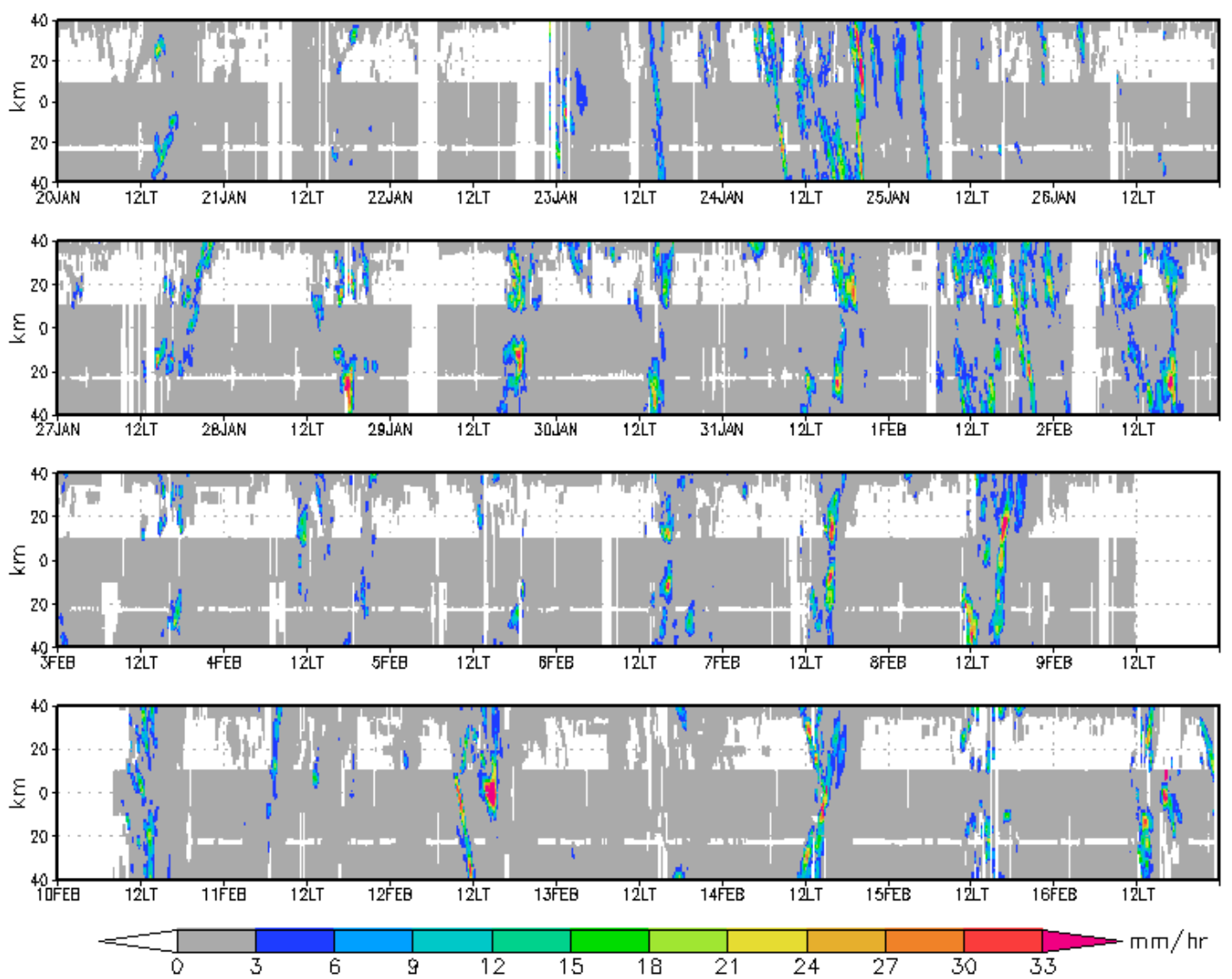

Gambar 4. Rataan dalam arah meridional (rataan longitudinal) intensitas hujan dari wilayah dalam kotak A pada gambar 1 selama periode IOP2016. Ordinat pada masing-masing plot menunjukkan jarak dari lokasi radar (misalnya, $40 \mathrm{~km}$ di sebelah atas adalah $40 \mathrm{~km}$ di sisi utara lokasi radar).
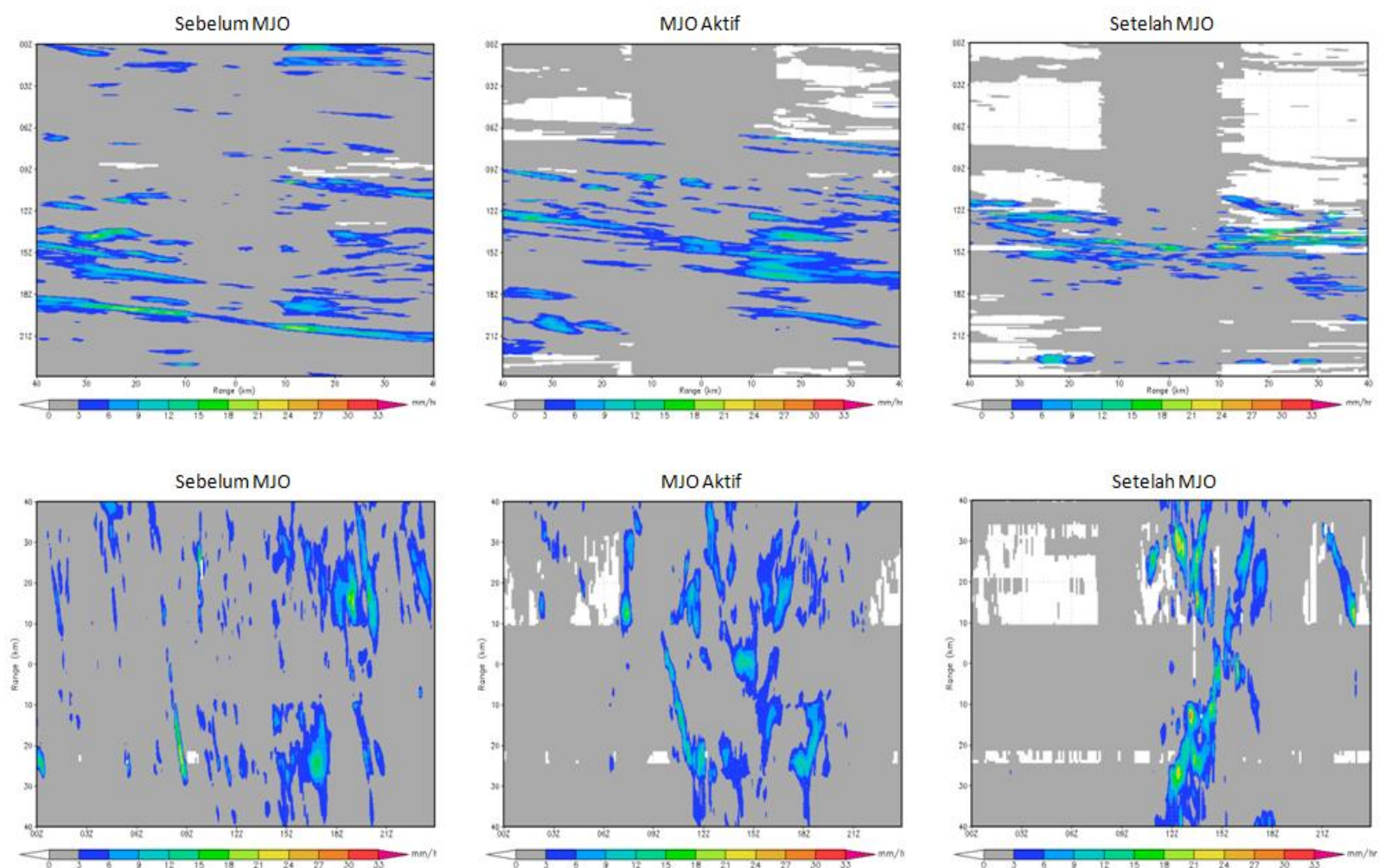

Gambar 5. Rataan 24-jam intensitas hujan selama 28 hari, dalam komponen zonal (atas), dan meridional (bawah) untuk masing-masing periode analisis. Simbol z pada ordinat plot zonal dan absis plot meridional menunjukkan waktu setempat (dalam WIB). 
Hal menarik yang bisa diamati pada periode ini adalah propagasi hujan yang dominan dari arah barat ke timur di sisi sebelah barat lokasi radar, sedangkan pada sisi timur, hujan terlihat lebih dominan bergerak dari timur ke barat. Intensitas hujan di sisi timur lokasi radar juga terlihat lebih tinggi dibandingkan pada sisi barat, walaupun secara keseluruhan, terlihat bahwa distribusi hujan pada periode setelah MJO aktif paling rendah dibandingkan pada periode sebelum dan saat MJO aktif.

Panel bawah dari Gambar 5 menunjukkan rata-rata 24 jam dari intensitas hujan selama 32 hari dalam komponen meridional. Terlihat bahwa distribusi hujan tertinggi terdapat pada periode sebelum MJO aktif, diikuti periode saat MJO aktif dan paling rendah pada periode setelah MJO aktif. Propagasi dominan hujan pada periode sebelum MJO aktif adalah dari utara ke selatan.

Pada periode MJO aktif tampak arah propagasi hujan mulai bervariasi setelah pukul 12LT, di mana hujan lebih banyak bergerak dari selatan ke utara, terutama di sisi selatan lokasi radar. Pada periode setelah MJO aktif, terlihat pola yang serupa dengan Gambar 3, kali ini dalam komponen meridional, di mana pada sisi utara lokasi radar hujan cenderung bergerak dari utara ke selatan, sedangkan di sisi selatan, hujan bergerak lebih dominan dari selatan ke utara, terutama setelah pukul 12 LT. Selain itu hujan dengan intensitas tertinggi juga terdapat pada periode setelah MJO aktif.

Perbedaan distribusi, intensitas serta propagasi hujan pada ketiga periode tersebut menunjukkan adanya interaksi yang cukup signifikan antara variasi diurnal, intraseasonal maupun seasonal selama periode IOP 2016. Monsun barat laut merupakan komponen paling dominan yang menyebabkan tingginya distribusi hujan selama periode IOP. Fenomena MJO aktif yang terjadi pada akhir Januari dan awal Februari 2016, terlihat menyebabkan penurunan distribusi hujan dan perubahan arah propagasi hujan pada periode tersebut, baik pada komponen zonal maupun meridional. Penurunan distribusi hujan di wilayah inland Jakarta dan sekitarnya pada fase aktif MJO tersebut sesuai dengan beberapa studi sebelumnya (Hidayat \& Kizu, 2010; Peatman et al., 2014) yang menunjukkan bahwa MJO lebih berpengaruh pada anomali positif curah hujan di wilayah perairan, dibandingkan di daratan. Studi yang dilakukan oleh Kamimera et al. (2012) dengan menggunakan data radar cuaca selama satu tahun di Sumatera Barat juga mengindikasikan bahwa curah hujan tertinggi justru terjadi ketika posisi MJO berada di Samudera Hindia (fase 3 ), sebelum memasuki wilayah Indonesia bagian barat.

Di sisi lain, pengaruh siklus diurnal terlihat paling dominan pada periode setelah MJO aktif (fase kering), ditandai oleh arah propagasi yang cukup signifikan dari selatan ke utara dan intensitas hujan yang tinggi menjelang sore hari.
Beberapa studi sebelumnya (Hidayat \& Kizu, 2010; Trilaksono et al., 2012; Wu et al., 2013) telah menunjukkan interaksi antara ketiga variasi tersebut secara singkat, namun tidak memberikan informasi lebih detil pada pengaruhnya di wilayah inland Jabodetabek karena keterbatasan data beresolusi tinggi. Pengaruh MJO terhadap siklus diurnal dalam komponen meridional yang ditemukan dalam penelitian ini juga melengkapi studi sebelumnya dengan radar cuaca oleh Kamimera et al. (2012) yang lebih banyak memaparkan pengaruh MJO terhadap siklus diurnal di Sumatera Barat dalam komponen zonal karena faktor topografi pulau Sumatera.

\section{KESIMPULAN}

Pengamatan hujan dengan menggunakan radar cuaca selama periode IOP2016 telah memberikan gambaran yang lebih jelas terhadap interaksi MJO dengan monsun barat laut dan siklus diurnal di wilayah Jakarta dan sekitarnya. Dari hasil analisis, diperoleh beberapa poin penting berikut:

1. Akibat pengaruh monsun yang dominan selama musim basah, hujan umumnya terjadi hampir sepanjang hari, terutama setelah sore hingga dini hari, serta bergerak dengan komponen zonal dari barat ke timur dan dari utara ke selatan pada komponen meridional.

2. Fenomena MJO yang terjadi pada akhir Januari 2016 dan awal Februari 2016 menyebabkan perubahan terhadap distribusi temporal dan propagasi hujan, baik dalam arah zonal maupun meridional.

3. Pada periode MJO aktif, distribusi hujan secara temporal terlihat berkurang dibandingkan dengan periode sebelum MJO aktif, terutama pada dini hari. Selain itu, hujan juga terlihat cenderung bergerak dari selatan ke utara setelah siang hari, yang menandakan pengaruh siklus diurnal yang semakin kuat dibandingkan periode sebelumnya.

4. Pada periode setelah MJO aktif, distribusi hujan berkurang secara signifikan secara temporal, namun intensitasnya bertambah. Hal ini menunjukkan bahwa siklus diurnal merupakan variasi yang paling berpengaruh terhadap hujan pada periode setelah MJO aktif, dibandingkan periode sebelum MJO aktif maupun periode saat MJO aktif.

Interaksi MJO terhadap monsun dan siklus diurnal yang ditemukan pada studi ini menarik untuk dikaji, karena berpengaruh kepada kejadian banjir Jakarta yang kerap terjadi pada musim hujan. Studi-studi sebelumnya menunjukkan bahwa, banjir Jakarta dipicu oleh monsun dan seruak dingin yang datang dari Laut Tiongkok Selatan dan Teluk Jakarta, menyebabkan terjadinya hujan lebat (torrential rain) yang umumnya terjadi pada dini hari (Trilaksono et al., 2012; Wu et al., 2013). 
Distribusi temporal hujan yang semakin berkurang ketika dini hari, terutama pada fase MJO aktif dan setelah MJO aktif, menunjukkan bahwa pengaruh monsun dan seruak dingin di wilayah Jakarta dan sekitarnya semakin berkurang pada kedua periode tersebut. Hasil penelitian ini mengindikasikan bahwa peluang terbesar terjadinya banjir Jakarta adalah pada periode sebelum MJO aktif, dan peluangnya semakin kecil pada fase aktif MJO dan setelah MJO aktif (fase kering), sesuai dengan studi yang dilakukan oleh Peatman et al. (2014) yang menunjukkan bahwa anomali positif hujan di wilayah daratan Jawa bagian barat terjadi sebelum fase MJO aktif.

Penelitian ini merupakan langkah awal untuk mempelajari karakteristik hujan di wilayah Jabodetabek, dengan hanya memanfaatkan parameter intensitas hujan dari data radar cuaca beresolusi tinggi. Beberapa parameter radar lainnya, seperti dBZ, ZDR dan KDP dapat dimanfaatkan untuk mengembangkan kajian ini selanjutnya, misalnya untuk identifikasi mikrofisika awan, estimasi hujan secara kuantitatif (Quantitative Precipitation Estimation) maupun untuk validasi data satelit (misalnya TRMM atau GSMaP).

\section{DAFTAR PUSTAKA}

Chang, C.P., Wang, Z., McBride, J., Liu, C.H. (2005). Annual Cycle of Southeast Asia Maritime Continent Rainfall and the Asymetric Monsoon Transition. Journal of Climate, 18(2), 287-301. doi: 10.1175/JCLI-3257.1

Hattori, M., Mori, S., Matsumoto, J. (2011). The Cross-Equatorial Northerly Surge over the Maritime Continent and Its Relationship to Precipitation Patterns. Journal of the Meteorological Society Japan, 89A, 27-47. doi: 10.2151/jmsj.2011-A02

Hidayat, R., Kizu, S. (2010). Influence of the Madden-Julian Oscillation on Indonesian Rainfall Variability in Austral Summer. International Journal of Climatology, 30(12), 1816-1825. doi: 10.1002/joc.2005

Hidayat, R. (2016). Modulation of Indonesian Rainfall Variability by the Madden-julian Oscillation. Procedia Environmental Science, 33, 167-177. doi: 10.1016/j.proenv.2016.03.067

Kamimera, H., Mori, S., Yamanaka, M.D., Syamsudin, F. (2012). Modulation of Diurnal Rainfall Cycle by the MaddenJulian Oscillation Based on One-Year Continuous Observations with a Meteorological Radar in West Sumatera. SOLA, 8, 111-114. doi: 10.2151/sola.2012028

Madden, R.A., Jullian, P.R. (1994). Observations of the 40-50-Day Tropical Oscillation - A Review. Monthly Weather Review, 122(5),
814-837.

doi:

$10.1175 / 1520$ 0493(1994)122<0814:OOTDTO>2.0.CO;2

Marshall, J.S., Palmer, W.McK. (1948). The Distribution of Raindrops with Size. Journal Meteor, 5, 165-166.

Mori, S., Hamada, J.-I., Sakurai, N., Fudeyasu, H., Kawashima, M., Hashiguchi, H., Syamsudin, F., Arbain, A.A., Sulistyowati, R., Matsumoto, M., Yamanaka, M.D. (2011). Convective System Developed along the Coastline of Sumatera Island, Indonesia, Observed with an X-Band Doppler Radar during the HARIMAU2006 Campaign. Journal of the Meteorological Society Japan, 89A, 61-81. doi: 10.2151/jmsj.2011-A04

Peatman, S.C., Matthews, A.J., Stevens, D.P. (2014). Propagation of the Madden-Julian Oscillation Through the Maritime Continent and Scale Interaction with the Diurnal Cycle of Precipitation. Quarterly Journal of The Royal Meteorological Society, 140(680), 814-825. doi: 10.1002/qj.2161

Peatman, S.C., Matthews, A.J., Stevens, D.P. (2015). Propagation of the Madden-Julian Oscillation and Scale Interaction with the Diurnal Cycle in a High-Resolution GCM. Climate Dynamics, 45, 2901-2918. doi: 10.1007/s00382-015-2513-5

Renggono, F., Hashiguchi, H., Fukao, S., Yamanaka, M.D., Ogino, S.Y., Okamoto, N., Murata, F., Sitorus, B.P., Kudsy, M., Kartasasmita, M., Ibrahim, G. (2001). Precipitating Clouds Observed by $1.3-\mathrm{GHz}$ Boundary Layer Radars in Equatorial Indonesia. Annales Geophysicae, 19(8). 889-897.

Tikno, S., Yahya, R.B., Syafira, S.S. (2016). Perbandingan Profil Hujan Vertikal Radar Cuaca dengan Micro Rain Radar Selama Kejadian Hujan Sedang (Studi Kasus: Intensive Observation Period 2016). Jurnal Sains \& Teknologi Modifikasi Cuaca, 17(2), 57-64.

Trilaksono, N.J., Otsuka, S., Yoden,S.. (2012). A Time-Lagged Ensemble Simulation on the Modulation of Precipitation over West Java in January-February 2007. Monthly Weather Review, 140(2), 601-616. doi: 10.1175/MWR-D-11-00094.1

Wheeler, M.C., Hendon, H.H. (2004). An AllSeason Real-Time Multivariate MJO Index: Development of an Index for Monitoring and Prediction. Monthly Weather Review, 132(8), 1917-1932. doi: 10.1175/15200493(2004)132<1917:AARMMI>2.0.CO;2

Wu, P., Hara, M., Fudeyasu, H., Yamanaka, M.D., Matsumoto, J., Syamsudin, F., Sulistyowati, R., Djajadihardja, Y.S. (2007). The Impact of Trans-Equatorial Monsoon Flow on the Formation of Repeated Torrential Rains over Java Island. SOLA, 3, 93-96. doi: 10.2151/sola.2007-024 
Wu, P., Arbain, A.A., Mori, S., Hamada, J-I., Hattori, M., Syamsudin, F., Yamanaka, M.D. (2013). The Effects of an Active Phase of the Madden-Julian Oscillation on the Extreme Precipitation Event over Western Java Island in January 2013. SOLA, 9, 79 - 83. doi: 10.2151/sola.2013018 